Consumer-factors Moderating Private Label Brand Success: Further Empirical Results

Mark S. Glynn

Shaoshan Chen

AUT University

A submission to the Special Issue on Retail Branding International Journal of Retail and Distribution Management.

Vol. 37 No. 112009

Accepted March 2009

CORRESPONDING AUTHOR:

Mark S. Glynn,

AUT Business School

AUT University,

Private Bag 92006,

Auckland 1142, New Zealand.

Phone: +6499219999

Email: mark.glynn@aut.ac.nz 


\title{
Consumer-factors Moderating Private Label Brand Success: Further Empirical Results
}

\begin{abstract}
Purpose- This research examines the category-level differences of both risk perception and brand loyalty effects on consumer proneness towards buying private label brands (PLBs).

Methodology/Approach- This study extends the work of Batra and Sinha (2000) (B\&S) by also examining the PLB effects of brand loyalty and price-quality by product category using a mallintercept survey.
\end{abstract}

Findings- The results indicate that quality variability, price consciousness, price-quality association and brand loyalty influence consumer proneness to buy PLBs. In addition, income, education and household size are moderators of PLB purchasing.

Research limitations/implications- This research confirms the importance of price consciousness and quality variability on PLB purchasing. The importance of these determinants depends on both the product category and the PLB market share within the category.

Practical implications- Retailers and manufacturers need to consider the effects of PLB in relation to the product category. For retailers the value of a PLB is less relevant in some categories but appealing to the price conscious consumer is important. Manufacturers should note in some categories that brand loyalty is important but not as much as price consciousness. Customer income is still an important determinant of PLB purchasing.

Originality and value- The study shows that it is important to consider product category differences which makes it more difficult to generalize about PLB purchasing.

Keywords- Private label brands, Product category, Brand loyalty, Demographics, Replication research.

Paper type- Research paper. 


\section{Introduction}

Private label brands are an important component of retail branding. Retail branding strategies typically consist of the store brand, the manufacturer's brand and the private label brand (Dawson 2006). Steenkamp and Dekimpe (1997) maintain that most conceptual and empirical research into branding focuses on manufacturer brands despite the growing importance of private label brands (PLB). Research shows that perceived risk, quality and price are important to PLB consumers. Despite the potential risks of PLB versus national brands, the market share of PLBs has been growing (Batra \& Sinha, 2000; Hoch \& Banerji, 1993). Furthermore, this PLB success is greater in Europe in comparison to North American and Asia-Pacific countries. In addition this PLB growth varies between product categories. For example, in New Zealand, PLBs have a 50\% share in fresh milk, but only an $9 \%$ share in the biscuit category (ACNielsen, 2003). Inter-category differences are an important source of variation in PLB share (Batra \& Sinha, 2000; Dhar \& Hoch, 1997). Batra and Sinha (2000) suggest that examining these inter-category differences may provide further insight into the development of PLBs.

Previous studies (e.g. (Burton, Lichtenstein, Netemeyer, \& Garretson, 1998; Garretson, Fisher, \& Burton, 2002) Dick, Jain and Richardson, 1995 and Richardson, Jain and Dick, 1996) examine general influences such as the economic and psychological factors affecting PLB purchase. However, the results from these studies are aggregated and do not consider product category differences. While some studies investigate PLBs from a cross category perspective, this research usually emphasises retailer and manufacturer competition and promotion (e.g. Hoch \& Banerji, 1993; Sayman \& Raju, 2004; Wedel \& Zhang, 2004). Inter-category research does not emphasise the consumer psychological effects of risk on PLB purchasing. 
This article reports a replication and extension of Batra and Sinha's (2000) (B\&S) study into PLB proneness. Replication research is important as it increases credibility of findings and permits further generalisations (Hubbard and Armstrong, 1994). However Hubbard and Armstrong note that replications are rare but suggest that such research is necessary to assess the validity, reliability and generalisability of many published studies. One notable example of replication research is the replications of Aaker and Keller's (1990) research. Individual replications of the Aaker and Keller study reveal additional findings that complement the findings of the original study (Bottomley and Holden, 2001).

This study extends the B\&S work using additional constructs and different product categories. The replication takes place in a different research setting (another country), providing a further test of the original hypotheses. International PLB research shows that grocery store brands in European countries have a higher brand equity compared to countries such as the US (Erdem, Zhao, \& Valenzuela, 2004). In New Zealand PLB market shares are relatively low but local grocery retailers have extended their store brand offerings in recent years. In addition to the antecedents of PLB purchasing in the B\&S study, we investigate the effects of two additional variables namely loyalty to manufacturer brands and the price-quality association. We further analyse these effects by category, and examine moderating influences such as demographic and market share on consumer PLB purchasing.

This paper consists of four sections. The first section provides a review of the consumer factors influencing PLB purchases. Second a description of research method of the study follows. The third section presents the findings including an analysis by category. In the final section the discussion of the findings concludes with the managerial implications and suggestions for future research. 


\section{PLB Purchasing Literature and Hypotheses}

This section reviews the literature on consumer-level antecedents of PLB purchasing and develops testable hypotheses. Information on consumer motivations of PLB purchasing enables retailers to enhance and differentiate their store offering. Early research addresses a key concern for manufacturers which is how the presence of PLBs in a category influences or erodes brand loyalty. Research that is more recent investigates the psychological perceptions of the PLB, and PLB customers as well as economic considerations such as price relative to quality. Perceived risk emerges as a critical factor that influences consumer intentions to buy PLB products (Batra \& Sinha, 2000; Bettman, 1973; Dunn, Murphy, \& Skelly, 1986; Richardson, Jain, \& Dick, 1996) and adopts a retail perspective. Richardson, Jain and Dick (1996) test a comprehensive framework in which quality, risk, external cues and demographic factors are antecedents of PLB purchasing. This review examines perceived risk factors for PLB purchasing and extrinsic measures such as price consciousness, brand loyalty and pricequality. Lastly the review examines the demographic influences inter category differences and PLB market share as potential moderating variables.

Prior studies show that the greater the perceived risk associated with PLBs, the lower the consumer PLB proneness (Dunn et al., 1986; Erdem, Zhao, \& Valenzuela, 2004; Richardson et al., 1996). Perceived risk has a number of facets: a functional risk (the PLB does not perform), a financial risk (wasting money) and social risk (the PLB may not be good enough for my friends). However, many studies treat 'perceived risk' as a single construct to predict consumer preferences for PLBs rather as a multidimensional phenomenon (Dunn et al., 1986). Furthermore Mieres, Martin and Gutierrez (2006) show that social risk is not a significant influence on PLB purchasing. Batra and Sinha (2000) examine this construct more closely using four determinants to explain PLB purchasing. These determinants are a greater 
consequence of making purchase mistake, quality variability between the PLBs and national brands in a category, the "search" versus "experience" nature of product features in a category and price consciousness. We now discuss each of these determinants in turn.

Consequences of making a purchase mistake is an important risk factor as consumers regard PLBs as being inferior to national brands on reliability, prestige, quality attributes (Bellizzi, Hamilton, Krueckeberg and Martin, 1981). When consumers consider that purchasing a wrong brand may have some important negative consequences, they are more likely to buy national brands. An explanation for this behaviour is that national brands provide a safer choice in many consumption situations (Baltas, 1997). Dunn et al. (1986) find that consumers regard PLBs as most risky on performance measures compared to national brands. Dunn et al.'s research also find that PLBs are least risky on financial measures, however social risk is less important for supermarket products generally. Other studies indicate that category involvement also negatively influences consumer attachment to PLB brands (Baltas and Doyle, 1998). In contrast, $B \& S$ focus on the risk aspects namely the costs and the immediate inconvenience of the purchase mistake of a PLB purchase. B\&S find no significant link in their initial analysis between consequences of a purchase mistake and PLB purchasing.

Perceived quality is a critical element in PLB purchase decisions (Hoch \& Banerji, 1993; Richardson et al., 1996)) and an important indicator of perceived risk (Narasimhan \& Wilcox, 1998). Although some major retailers continually improve their PLB quality (Rafiq \& Collins, 1996), consumers remain suspicious of PLB quality (Dick, Jain, \& Richardson, 1995). Product quality variability across different brands also adds to this consumer uncertainty (Erdem et al., 2004). Several studies show that product quality consistency negatively impacts on PLB performance (Erdem et al., 2004; Hoch \& Banerji, 1993; Steenkamp \& Dekimpe, 1997). Hoch and Banerji (1993) point out that product quality is important in 
explaining the market shares of PLBs. Their work suggests that PLB products are more successful in categories where PLB quality is closer to that of national brands. Semeijn et al. (2004) conclude that when quality variance within a product category is high, consumers will choose manufacturer brands over private labels, to reduce perceived risk of that purchase. Dick et al. (1995) also show that PLB proneness is higher when there is a lower quality differential between PLBs and national brands. However B\&S show that quality variability only is an indirect influence when consequences of a purchase mistake mediates PLB preference. This finding contradicts other studies which show that quality variability has a direct and negative influence on PLB proneness (Dick et al., 1995; Hoch \& Banerji, 1993; Semeijn, Riel, \& Ambrosini, 2004).

Another determinant of category-specific perceived risk is the nature of the product attributes of the category. In this instance, whether consumers need to "search" for information versus attributes that require consumer trial in order to judge a product. Search attributes refer to the tangible features that are verifiable before product purchase, whereas experience attributes refer to the not-easily-described features that can be confirmed only through product use. Consumers have less uncertainty and perceived risk in product categories with more search than experience attributes (Erdem and Swait, 1998). B\&S find that consumers prefer national brands to PLBs in product categories where they cannot rely on the product packaging information to assess accurately product quality. However, other studies indicate that PLBs usually suffer from a lack of extrinsic cues such as a brand name and packaging relative to national brands (Bellizzi, Hamilton, Krueckeberg, \& Martin, 1981; Cunningham, Hardy, \& Imperia, 1982; Dick et al., 1995; Richardson, Dick, \& Jain, 1994). Thus depending on search attributes to assess product quality may offset PLB proneness and increase the perceived risk associated with PLB buying. Experience characteristics are more ambiguous than search attributes (Batra \& Sinha, 2000). Therefore, including sufficient search attributes to 
compensate for the ambiguity and uncertainty created by experience attributes should increase consumer PLB proneness. B\&S show search and experience was positively related to PLB purchasing initially.

Besides examining these three perceived risk determinants $B \& S$ also include price consciousness as a measure of income effects on PLB purchase. Price consciousness is the degree to which consumers use price in its negative role as a decision-making criterion (Lichtenstein, Bloch, \& Black, 1988). Since PLBs are typically lower in price relative to national brand products, studies have often used price consciousness as one of the attitudinal characteristics of PLB buyers. Price consciousness is relevant to both national brands and PLBs. Raju, Sethuraman and Dhar (1995) confirm that PLB products perform well in product classes where consumers are more price sensitive. Burton et al. 1998 and Ailawadi et al. (2001) also show that consumers who tend to pay low prices have a more favourable attitude towards buying PLBs. Erdem et al. (2004) show that the greater price sensitivity of UK compared to US consumers explains why PLBs are more successful in the UK than the US.

B\&S hypothesise that quality variation, search, purchase mistake outcomes and price conscious directly affect PLB purchase. B\&S find that only price consciousness and one perceived risk factor search positively affects PLB purchasing. A suggested alternative model by $B \& S$ did not provide any better fit with the data, thus we restate their initial three hypotheses and include an additional hypothesis $\mathrm{H}_{1 \mathrm{~d}}$ based on their original model.

$\mathrm{H}_{1 \mathrm{a}}$ : Consumers are more prone to buying private label brands where they perceive lower consequences of making a mistake in their brand selection.

$\mathrm{H}_{1 \mathrm{~b}}$ : Consumers are more prone to buying private label brands where they perceive lower variability in quality across brands. 
$\mathrm{H}_{1 \mathrm{c}}$ : Consumers are more prone to buying private label brands where they can accurately gauge the product quality of important attributes and benefits based on written descriptions alone (Search vs Experience).

$\mathrm{H}_{1 \mathrm{~d}}$ : Consumers are more prone to buying private label brands where they are more price conscious.

As well as the four determinants examined by B\&S, other constructs also influence PLB purchasing. Richardson et al. (1996) highlight consumer the reliance on extrinsic cues such as brand names in PLB decision making. Furthermore B\&S find an insignificant link between quality variability and PLB purchase, which contradicts Richardson et al.'s (1996) results. Thus we examine the effect of two other determinants price-quality association and brand loyalty on PLB purchasing. Price-quality association is the belief across product categories that the level of a price cue is related positively to the level of product quality (Lichtenstein, Ridgway, \& Netemeyer, 1993). Consumers may perceive the product as being inferior in overall quality (Burton et al., 1998; Garretson et al., 2002). Several PLB studies show that price-quality associations have a negative influence on PLB attitude and purchase (Burton et al., 1998; Garretson et al., 2002; Wolinsky, 1987). Therefore, the low prices may only exacerbate further any unfavourable quality perceptions of PLB products (Richardson et al., 1996). Similar findings from Ailawadi et al. (2001), Burton et al. (1998), and Garretson et al. (2002) also show the weaker the price-quality association, the more favourable the attitude towards PLBs and the higher the purchase incidence of PLBs.

$\mathrm{H}_{2 \mathrm{a}}$ : Consumers are less prone to buying private label brands where they have increased price quality perceptions. 
Higher distribution intensity gives national brands an advantage in terms of extrinsic cues over PLBs that only have store availability. Brand-loyal consumers usually have a habit of purchasing a particular national brand due to an emotional attachment and satisfaction with previous purchases (Lim \& Razzaque, 1997). Prior research suggests that price conscious consumers are less brand loyal, instead exhibiting strong variety seeking behaviour (Garretson \& Burton, 1998; Garretson et al., 2002). Frequent PLB purchasers also show similar buying behaviour. Baltas (1997) notes PLB-prone buyers are likely switchers or variety seekers who do not have a stable brand selection. These consumers can easily switch to national brands when the price gap between PLBs and national brands is narrowed (Blattberg, 1980; Livesey \& Lennon, 1978; Putsis \& Cotterill, 1999). Brand loyalty is inversely related to the incidence of PLB purchase (Ailawadi, Neslin, \& Gedenk, 2001; Burton et al., 1998; Garretson et al., 2002). However the loyalty measures in these scales do not refer specifically to national brands. Furthermore brand comparisons often takes place instore and retailer display decisions for instance can negatively influence national brand evaluations (Buchanan, Simmonds, and 1999). Moreover a key concern for manufacturers is the erosion of brand loyalty by PLBs (Quelch and Harding 1996). Overall, the literature indicates that PLB purchasing indirectly influences negatively by brand loyalty.

$\mathrm{H}_{2 \mathrm{~b}}$ : Brand loyalty reduces consumer proneness to buying private label brands.

Another issue important to both retailers and marketers is whether the effect of demographic groups influences attitudes towards private labels. Research has found that consumer sensitivity to quality, risk and price affects PLB proneness (Erdem et al. 2004). Richardson et al. (1996) contend that as PLBs are sold at a lower price, the demographic status of respondents affects the propensity to purchase. However, Baltas and Doyle (1998) conclude that many of the demographic findings into PLB purchasing are mixed, unclear or outdated. 
As some of the research on demographic PLB effects is contradictory, we next examine the influence of age, household income, education, and household size, together with the relevant hypotheses.

Contradictory findings in the literature exist as to the influence of age group on PLB purchasing. Richardson et al. (1996) suggests the experience of older shoppers makes them more likely to consider PLBs as viable alternatives to national brands, although the evidence did not support this hypothesis. This viewpoint implies that older people have more budget constraints, they may be more price sensitive and thus more likely to purchase a PLB (Omar 1996). An alternative explanation is that older people avoid PLBs; whereas younger people are more likely to accept them. Dick et al. (1995) found that older shoppers purchased national brands while younger consumers favoured PLBs.

$\mathrm{H}_{3 \mathrm{~b}}$ : Consumer buying proneness of private labels is determined by age.

Hoch (1996) suggests that household income has a negative relationship with PLB purchase. Richardson et al. (1996) examine the effect of educational achievement on PLB purchasing. Highly educated consumers have more opportunity to earn a greater income and are less dependent on the brand name as an extrinsic cue (Murphy \& Laczniak, 1979). Some researchers also show that PLB buyers with lower formal education are more likely to purchase national brands (Richardson et al. 1996). Other researchers argue that well educated consumers are more confident in their evaluative ability of products and that education is positively related to PLB performance. Richardson et al. (1996) suggests that larger households, who have fewer financial resources than smaller households, are more likely to purchase PLBs. 
$\mathrm{H}_{3 \mathrm{c}}$ : Consumers are less prone to buying private label brands where they have more household income.

$\mathrm{H}_{3 \mathrm{~d}}$ : Consumers are less prone to buying private label brands where they have more formal education qualifications.

$\mathrm{H}_{3 \mathrm{e}}$ : Large households are more prone to buying private label brands.

Category variations for PLB purchases are evident in other studies (Batra \& Sinha, 2000; Dunn et al., 1986; Hoch \& Banerji, 1993; Prendergast \& Marr, 1997). Dunn et al. (1986) found that consumers perceive higher performance risk in ice cream than in fabric softener and laundry detergent. Prendergast and Marr (1997) also show that consumers evaluate PLBs in categories such as rice and tissues more favourably than categories such as shampoo and coffee. B\&S (2000) test their model aggregating data from several categories, but did not conduct a model at the individual category level. Dhar and Hoch (1997) show that the penetration of a PLB depends on retailer commitment to the category as well as the underlying quality of the store brands offered. Zielke and Dobbelstein (2007) find for a new store brand introduction, each product category conveys different aspects of purchase risk such as social acceptance, which influences willingness to buy. A similar approach was taken by Kwon, Lee and Kwon (2008), who found that value consciousness moderates these category characteristics. However extant research does not consider how willingness to purchase PLBs is affected by the strength of the private label market share within the category. Erdem et al. (2004) show that in countries such as the UK, PLB share is affected by greater risk, reduced price-quality evaluations and lower brand loyalty which leads to the fourth hypothesis.

$\mathrm{H}_{4}$ : That PLB purchasing is moderated by differences in PLB category share. 


\section{Methodology}

Data were collected from a mall-intercept survey (used by B\&S) conducted in a New Zealand city supermarket. This method has many advantages, which include: ease of establishing rapport with shoppers, the ability to clarify responses to survey questions and immediate collection of survey responses. In addition, Sudman (1990) states by sampling participants at all mall entrances equally will result in an unbiased sample. Every third shopper was selected and a screening question was used asking whether participants had made a purchase in one of ten product categories with a private label offering. With the B\&S study respondents evaluated three categories, however for this study respondents only evaluated one category, thus reducing the response burden.

Six determinants of private label purchase were measured using extant multi-item scales. The first four $(\mathrm{B} \& S)$ are: consequences of making a mistake in a purchase, quality variability, and the search versus experience nature of product features in a category, and price consciousness. The remaining two determinants are brand-loyalty and price-quality association. The scale items and their sources are shown in table I. In the B\&S study three of the four scales contained only two items per scale, which prevents scale reliability from being established. B\&S therefore suggest that better measures of these constructs need developing. As a result, additional items for these scales were included in order to achieve a minimum of three items per construct as per Hair et al. (1998)'s recommendations to achieve construct reliability.

The dependent variable is whether the respondent buys either private labels or national brands and is measured by a five point likert scale $(B \& S)$. Respondents were questioned about these six determinants in relation to one of ten product categories selected by the interviewer. Within each category, private label brands accounted for different market share levels shown 
in table I. In four categories the market share was above $25 \%$ while in the remaining categories the PLB share was lower than 25\%. In the survey, intercepting 665 shoppers resulted in 600 usable questionnaires. Sixty responses were obtained for each of the ten categories, which are: canned fruit, biscuits, toilet tissue, pet food, fresh milk, bread, breakfast cereal, fruit juice, cheese and potato chips. Furthermore as each of these categories differ from B\&S, this study provides a further test of their hypotheses.

Take table I here.

$\mathrm{B} \& S$ analyse the data by means of a structural equation analysis, of the exogenous variables in Hypothesis $1_{\mathrm{a}-\mathrm{d}}$ on the dependent variable. In the original study only 2 of the 4 hypotheses were significant. The additional constructs brand loyalty and price quality also influence PLB purchasing. As there is only one dependent variable and six independent variables, multiple regression is more appropriate to analyze the data (Hair et al, 1998). To achieve conceptually meaningful independent variables the data checks for reliability and validity use both exploratory factor analysis (EFA) and confirmatory factor analysis (CFA).

To test that these items and constructs had discriminant validity these constructs were subjected to an EFA. The data met the criteria for EFA as there were sufficient cases per item, the Bartlett test of sphericity was met, the normality of the dataset was satisfactory and there were minimal missing data and outliers. The EFA consisted of a principal components analysis with a varimax rotation. Six factors were extracted from this analysis, with eigenvalues over 1.0 and explaining $60.4 \%$ of the variance. In the analysis factor loadings above $+/-0.40$ were retained and each item loaded on the correct construct. As a result in one item per construct which had either had a cross-loading or a loading less than 0.4 was deleted. These six factor loadings were then saved as summated scores for use as independent 
variables in the multiple regression. To test for validity of these measures the items were subject to a CFA. Unidimensionality is shown by each of the items loading correctly on to their construct, convergent validity is indicated with all standardised factor loadings being over 0.50 and significant $t$ values exceeding the 1.96 threshold. Discriminant validity is shown as the average variance extracted exceeds the squared correlation for each construct. The measurement model shows a good fit to the data: $\chi^{2} / d f=3.64, p=0.000, \mathrm{CFI}=0.94$, $\mathrm{NNFI}=0.92, \mathrm{AGFI}=0.91$ and RMSEA=0.066. While the theoretical specification of the model is good, two constructs search and purchase mistake have low reliability scores and only two items per scale were used. However, for theoretical completeness all constructs have been included in the regression analysis (Hair et al. 1998). Table I shows that the other constructs quality variability, price consciousness, price-quality and brand loyalty all have three items per scale and show good reliability.

\section{Findings}

The descriptive statistics are shown in table II. The $1^{\text {st }}$ column shows the private label share of the category Nielsen (2003) where the canned fruit, toilet tissue, milk and cheese categories have more than $25 \%$ share. The category that has the highest price consciousness is canned fruit which also has highest likelihood of a private label purchase, while the category with the lowest price consciousness was bread. An ANOVA with a Scheffe test shows both mean scores are significantly different at $p<0.05$. Respondents are most brand loyal to breakfast cereals and pet food, which also has the lowest incidence of private label purchase, but are least loyal to fresh milk. Fresh milk with the highest PLB share ranks the lowest for quality variability and price quality. Bread, a category with no private label presence also shows a low search mean score. Table II also shows the comparison of mean scores for each category. The mean scores of the four constructs from the B\&S study show a similar response level to the original findings. 
Take table II here.

The regression results are in table III. This table shows the model is significant both overall ( $\mathrm{R}^{2}$ explains 20.0 percent of the variance) and with four of the six regression coefficients. The consequences of a purchase mistake are marginally significant at $p<0.10$, while search was non-significant. The standardised coefficients show as with B\&S, that price consciousness has the strongest regression coefficient, and is in a positive direction confirming $\mathrm{H}_{1 \mathrm{~d}}$. Unlike $\mathrm{B} \& \mathrm{~S}$ 's results however, quality variability was significant but in a negative direction. This finding confirms Batra and Sinha's original hypothesis and our hypothesis $\mathrm{H}_{1 \mathrm{~b}}$. The other independent variables brand loyalty and price-quality association are also significant and in a negative direction supporting both $\mathrm{H}_{2 \mathrm{a}}$ and $\mathrm{H}_{2 \mathrm{~b}}$. Respondents consider such purchase decisions are less consequential with marginal support for $\mathrm{H}_{1 \mathrm{a}}$ and are neutral towards the usefulness of product information on the packaging (search), rejecting $\mathrm{H}_{1 \mathrm{c}}$.

Take table III here.

Batra and Sinha (2000) provide descriptive statistics showing inter-category differences, but do not conduct a multivariate category analysis. As the sample size in our study for each category satisfies the requirements for a multivariate analysis (Hair et al. 1998), we conduct multiple regressions on each product category. These results in Table IV show first the explained variance $\mathrm{R}^{2}$ by category of the dependent variable and second the significance of the individual standardised coefficients for the independent variables. In only one category, potato chips, was the regression model not significant. Among the remaining significant nine categories, canned fruit has the highest $\mathrm{R}^{2}$ at 33.1 percent while the cheese co-efficient of 
determination explains the lowest amount of variance at 17.8 percent. The individual category regression analyses explain more variance than the overall regression in Table III.

Turning to the independent variables, price consciousness is significant for seven categories except for toilet tissue and biscuits. Price consciousness is high for canned fruit and fresh milk. The price-quality association is significant in a negative direction only with the biscuit category. Brand loyalty was significant for seven categories of the nine particularly biscuits but not in canned fruit or cheese. The brand loyalty result confirms a negative relationship to PLB purchasing. Quality variability is significant also in a negative direction only in the toilet tissue-the highest as well as the pet food and breakfast cereal categories.

Take table IV here.

To test the moderating hypotheses $\mathrm{H}_{3 \mathrm{a}-} \mathrm{H}_{3 \mathrm{e}}$ of the demographic groups, a t-test and one-way ANOVAs were employed. Testing for gender differences shows no difference in private label purchasing between males and females $(\mathrm{t}=0.662, p<0.508)$, thus this hypothesis $\mathrm{H}_{3 \mathrm{a}}$ is not accepted. For $\mathrm{H}_{3 \mathrm{~b}}$ there are no differences among the age-groups $(\mathrm{F}=1.328, p<0.258)$ therefore this hypothesis was also not accepted. However testing for differences among the educational achievement of respondents shows a significant difference $(\mathrm{F}=2.598, p<0.035)$, thus $\mathrm{H}_{3 c}$ was accepted. There were also differences evident among different income groups ( $\mathrm{F}$ $=5.299, p<0.000$ ) therefore $\mathrm{H}_{3 \mathrm{~d}}$ was also accepted. Finally the ANOVA also shows a marginally significant effect for household size on private label purchase $(\mathrm{F}=2.103, p<$ 0.099), therefore $\mathrm{H}_{3 \mathrm{e}}$ is also accepted.

The final analysis contrasts the antecedents of PLB purchasing with actual private label market share and tests hypothesis 4 . Separate regression analyses are run with data from the high share and low share PLB categories with the results shown in Table V. For the high 
PLB categories only price consciousness is significant. In contrast for the low PLB categories price consciousness, price quality and brand loyalty were significant. Brand loyalty has the largest beta coefficient and this model is significant with an $\mathrm{R}^{2}$ explaining nearly $20 \%$ of the variance. A Chow test (Chow, 1960) was conducted to compare the differences between the two regression equations in table $\mathrm{V}$.

The Chow test examines differences between the regression equations for the two groups. If there are no differences between the high and low PLB share groups, then this implies the independent variables are equal. A Chow test was conducted on the pooled sample of both groups. The Chow statistic has an $\mathrm{F}$ distribution with $(k, n 1+n 2-2 k)$ degrees of freedom. The Chow test statistic gave an F value of 3.92, which is less than the cut off value of 8.53 for

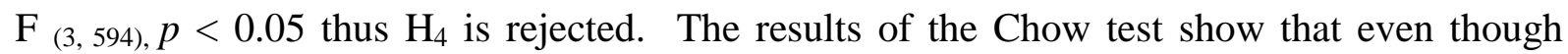
differences in the individual regression coefficients are evident, the combined effect of these independent variables on PLB purchasing is similar for both the high and low PLB share groups.

\section{Discussion}

This replication and extension study confirms some aspects of Batra and Sinha's research, but also provides interesting contrasts. First this study did produce a more robust scale for the price consciousness measure which in B\&S only had two items per scale. In both studies price consciousness has the strongest effect on PLB purchasing and is relevant to most categories. Price consciousness was the only construct to replicate across both studies and across most of the categories in this study. Thus an improved price consciousness scale is a contribution to the PLB literature. 
Both search and consequences of a purchase mistake also had two items per scale, despite attempts to develop a better scale. This finding indicates these two scales are not robust in PLB research and are less important for consumers in decision making for fast moving goods. The results of our study for quality variation show a significant effect on PLB, whereas the $\mathrm{B} \& \mathrm{~S}$ results are initially non-significant. Thus our research confirms the B\&S original hypothesis. However there is no support for search vs experience $\mathrm{H}_{1 \mathrm{~b}}$ in contrast to $\mathrm{B} \& \mathrm{~S}$. Furthermore our analysis shows that consumers risk perceptions, price quality and brand loyalty towards PLB purchasing vary by category which may further explain the differences in our results compared with B\&S.

This study shows that PLB market share does not moderate the antecedents of consumer PLB proneness. These findings show that brand loyalty, quality variability and price quality are not important in categories where consumers are buying PLBs anyway. Where PLBs have less market share, constructs that differentiate manufacturer's brands such as brand loyalty, price quality and quality variability are still very relevant to shoppers.

Price consciousness strongly affects PLB buying in most categories such as canned fruit and milk, but not in others like potato chips, biscuits and toilet tissue. In potato chips and biscuits, wide price variations exist within these categories, whereas less variation exists in canned fruit and fresh milk in terms of price. The results suggest that price consciousness may be related to price variation of all brands within the category.

PLB purchasing also is higher in categories where consumer perceptions of quality variability between national brands and PLBs are lower. Quality variability influences PLB purchase in functional categories such as toilet tissue, but was less relevant in the other categories. These 
results are similar to $B \& S$ and show that overall quality variability does not affect PLB proneness, in contrast to previous research (e.g Hoch and Banerji, 1993).

The negative relationship between price-quality association and PLB purchasing was only strongly evident in the biscuit category which has a range of price points and quality levels. This study shows that price-quality association is important only in categories with a low PLB share. Customers who were brand loyalty was apparent in low PLB categories too. Brandloyal consumers are likely to have more concerns about quality (East, Gill, Hammond, \& Hammond, 1995) and engage in lower variety-seeking behaviours (Garretson et al., 2002), thus PLB products may not be an alternative in their consideration set. This negative relationship is similar to Burton et al. (1998) and Garretson et al. (2002)s' findings. The consequences of a purchasing mistake was marginally significant but not significant amongst the regressions of the individual categories. This finding while stronger than $\mathrm{B} \& \mathrm{~S}$ is broadly in line with their conclusions. Search and experience does not appear to be a significant influence on PLB purchasing in either study. This result could indicate that consumers were very familiar with these categories from previous usage and experience.

This study indicates that households with higher incomes are less likely to buy PLB products. Such households have fewer financial constraints and show less price concern (Ailawadi et al., 2001). This finding is consistent with Burton et al. (1998) who show that higher-income families have a less favourable attitude to PLBs, which reduces PLB purchase incidence. Moreover, this study shows that the relationship between education and PLB purchase is significantly negative. Consumers who have tertiary-level education are more likely to choose higher priced national brands than people without such qualifications. This study suggests that people with higher educational qualifications are less prone to choose PLB products. In contrast, Lybeck, Holmlund-Rytkönen and Säärksjärvi (2006) find that better 
educated consumers bought store brands. In addition, this research confirms that age and gender are not important in identifying PLB-prone purchasers, which is consistent with Burton et al.'s (1998) findings. However Lybeck et al. (2006) find that middle-aged consumers are more likely to buy store brands. Furthermore, household size is a significant characteristic that differentiates PLB from national brand buyers. A household size effect on PLB purchase is also supported by Burton et al. (1998), Dick et al. (1995) and Hoch (1996).

In summary, the results suggest that examining aggregrate findings from several categories concerning consumer attitudes towards PLBs does not explain the variation amongst individual categories. Price consciousness was a consistently significant influence on PLB purchasing in both studies. Furthermore quality variability of the category was also significant in our results but not in the B\&S study. In addition, brand loyalty and pricequality perceptions negatively affect PLB purchasing. However when individual categories were examined many risk and quality factors were not significant. Furthermore these risk and quality factors only apply to categories with a low PLB share. As well as these more general implications, this study shows that category differences exist but do not affect PLB purchasing. Some demographic influences are also important moderating variables.

\section{Implications}

There are several implications for retail branding. First, a range of consumer factors such as perceived risk and attitude greatly affect PLB buying (Batra \& Sinha, 2000; Dunn et al., 1986; Richardson et al., 1996). Examining these factors can identify the areas of strength and vulnerability for private label brands. Furthermore these determinants vary by category. Retailers should be aware that demographic influences moderate consumer propensity to buy PLBs. For retailers, low price is important and underlines the need to maintain low-price PLB strategies to attract price-conscious consumers to PLBs and discourage them from 
switching back to national brands in the long term. Corstjens and Lal (2000) suggest that without a combination of low price and high quality, PLB brands cannot be successful. To improve the competitive position for PLBs, a quality focus may be useful (Choi and Coughlan, 2000). Thus, retailers should pay close attention to maintaining and improving quality of their PLBs in an attempt to increase PLB share. These efforts could be accomplished by improving the quality of ingredients, as well as the packaging, design and labelling. Moreover, retailers could take advantage of their store environment and store image to communicate the high quality of PLBs to consumers through displays, in-store taste-trial activities and free samples (Sprott and Shimp, 2004). Purchase incidence will increase when consumers perceive PLBs as "good quality for a low price" not "low quality for a low price".

Besides improving the quality of PLBs, retailers should also be aware of the quality variability between PLBs and national brands. This research suggests that while retailers can improve PLB products in the hope of reducing the quality gap with leading national brands, this strategy may be counterproductive unless retailers address the price-quality aspects. Finally, retailers could avoid head-on competition with brand manufacturers by targeting PLB consumers from different demographic groups compared with national-brand buyers. For instance, retailers may more effectively use PLBs in store locations where consumers have low household incomes or where retailer have a price-driven store format/image.

This research confirms the importance of manufacturer brand loyalty which reduces consumer proneness towards buying PLBs. For national-brand manufacturers, temporary price reductions which appeal to price-conscious consumers may be an effective way of competing against PLBs in the short term. However, it may not be wise to run such promotions frequently or long-term, because the results may have a negative impact on the brand success once the promotion is removed (Blattberg, Briesch, \& Fox, 1995). Since it is difficult to 
cancel out the price differential with PLB products (Baltas, 1997), competing pricewise with PLBs on a regular basis could be ineffective. Manufacturers are better differentiating their national brands from PLBs through superior quality and using extrinsic cues such as brand image and innovation. This strategy may be more effective as retailers often do not have the research and development capability to compete with national brands.

As price-quality association has a favourable influence on national brand performance, manufacturers could emphasise price-quality aspects in their marketing communication. Manufacturers could also extend their brands to other categories by demonstrating that pricequality patterns in an established category are indicative of the brand in a new category. These findings show that PLB purchasing is category dependent. In high PLB share categories perception of risk, quality and brand loyalty are of less concern to shoppers. Whereas in low PLB share categories, price quality and brand loyalty are important considerations which both manufacturers and retailers should be conscious of.

There are several limitations in this research. First, this study focuses only on the supermarket industry. The results may not be generalisable to other retailers such as durablegoods or fashion retailers. Second, the data collected is only from a single supermarket source; however this approach is consistent with B\&S. Since PLB performance varies across different retail stores and depends on the retailer's overall marketing strategy, consumer perceptions of PLB purchasing may also differ. Measurement on a single occasion may also affect the reliability of the measured constructs (Burton et al., 1998; Epstein, 1979). The sample size for the individual categories while meeting multivariate analysis criteria, may have yielded more significant regression coefficients if more responses per category were available. 
Several areas for future research are suggested. First, similar research could examine whether these consumer influences apply to areas such as apparel and technology retailing. Second, this regression analysis only explains $20 \%$ of the variance and focuses on product related attributes such as quality and price. As retailers also emphasise non-product attributes such as brand image in their store and private label marketing communication, research could also examine the relative influence of these non-product attributes. Third, further research could examine the category characteristics to further understand the variations reported in this study and their potential effects on market share. Some studies examine the extrinsic aspects of the category such as category involvement (Kwon et al., 2008) and functional/hedonic aspects (Zeilke and Dobblestein, 2007). However this study suggests the nature of the category, including the amount of product variety and price variation, could be further examined.

In conclusion the replication and extension of $\mathrm{B} \& \mathrm{~S}$ confirms some of the original findings but also highlights some differences. First several risk and quality determinants explain why consumers are more prone to PLBs than national brands. Second the importance of these determinants varies by product category. Category-specific analysis better explains the variations in purchasing preferences for PLB products. Retailers should therefore consider which determinants are important for an individual category perspective. Third, as price consciousness was the most important PLB purchase determinant, customer demographics such as household income are still important moderators. As well as being an important store differentiator in retail branding, retailers should be aware that PLB growth may be inhibited in a local trading area because of an over-representation of particular customer groups. Fourth, how well the PLB performs within the category determines which risk factors consumers consider important but these differences do not affect PLB purchasing overall. 


\section{References:}

ACNielsen. (2003). Market Information Digest. New Zealand.

Ailawadi, K. L., Neslin, S. A., \& Gedenk, K. (2001). Pursuing the value-conscious consumer: Store brands versus national brand promotions. Journal of Marketing, 65(1), 71-89.

Baltas, G. (1997). Determinants of store brand choice: a behavioral analysis. The Journal of Product and Brand Management, 6(5), 315-324.

Batra, R., \& Sinha, I. (2000). Consumer-level factors moderating the success of private label brands. Journal of Retailing, 76(2), 175-191.

Bellizzi, J. A., Hamilton, J. R., Krueckeberg, H. F., \& Martin, W. S. (1981). Consumer Perceptions of National, Private, and Generic Brands. Journal of Retailing, 57(4), 5670.

Bettman, J. R. (1973). Perceived risk and its components: A model and empirical test. JMR, Journal of Marketing Research (pre-1986), 10(2), 184-190.

Blattberg, R. C. (1980). Segmentation Strategies for New National Brands. Journal of Marketing (pre-1986), 44(4), 59-67.

Blattberg, R. C., Briesch, R., \& Fox, E. J. (1995). How promotions work. Marketing Science, 14(3), 122-132.

Burton, S., Lichtenstein, D. R., Netemeyer, R. G., \& Garretson, J. A. (1998). A scale for measuring attitude toward private label products and an examination of its psychological and behavioral correlates. Academy of Marketing Science. Journal, 26(4), 293-306.

Cunningham, I. C. M., Hardy, A. P., \& Imperia, G. (1982). Generic Brands Versus National Brands and Store Brands. Journal of Advertising Research, 22(5), 25-32.

Dhar, S. K., \& Hoch, S. J. (1997). Why store brand penetration varies by retailer. Marketing Science, 16(3), 208-227.

Dick, A., Jain, A., \& Richardson, P. (1995). Correlates of store brand proneness: Some empirical observations. The Journal of Product and Brand Management, 4(4), 15-22.

Dunn, M. G., Murphy, P. E., \& Skelly, G. U. (1986). Research Note: The Influence of Perceived Risk on Brand Preference for Supermarket Products. Journal of Retailing, 62(2), 204-216.

East, R., Gill, P. H., Hammond, W., \& Hammond, K. (1995). Correlates of First-brand Loyalty. Journal of Marketing Management, 11(5), 487-497. 
Epstein, S. (1979). The Stability of Behavior: I. On Predicting Most of the People Much of the Time. Journal of Personality and Social Psychology, 1097-1126.

Erdem, T., Zhao, Y., \& Valenzuela, A. (2004). Performance of Store Brands: A CrossCountry Analysis of Consumer Store-Brand Preferences, Perceptions, and Risk. JMR, Journal of Marketing Research, 41(1), 86-100.

Garretson, J. A., \& Burton, S. (1998). An examination of the economic, shopping-related, and psychological profiles of highly coupon and sale prone consumers. American Marketing Association. Conference Proceedings, 9, 36-37.

Garretson, J. A., Fisher, D., \& Burton, S. (2002). Antecedents of private label attitude and national brand promotion attitude: Similarities and differences. Journal of Retailing, 78(2), 91-99.

Hoch, S. J., \& Banerji, S. (1993). When do private labels succeed? Sloan Management Review, 34(4), 57-67.

Lichtenstein, D. R., Bloch, P. H., \& Black, W. C. (1988). Correlates of Price Acceptability. Journal of Consumer Research, 15(2), 243-252.

Lichtenstein, D. R., Ridgway, N. M., \& Netemeyer, R. G. (1993). Price perceptions and consumer shopping behavior: A field study. JMR, Journal of Marketing Research, 30(2), 234-245.

Lim, K. S., \& Razzaque, M. A. (1997). Brand loyalty and situational effects: An interactionist perspective. Journal of International Consumer Marketing, 9(4), 95-115.

Livesey, F., \& Lennon, P. (1978). Factors Affecting Consumers' Choice Between Manufacturer Brands And Retailer Own Labels. European Journal of Marketing, 12(2), 158-170.

Murphy, P. E., \& Laczniak, G. R. (1979). Generic Supermarket Items: A Product and Consumer Analysis. Journal of Retailing, 55(2), 3-14.

Narasimhan, C., \& Wilcox, R. T. (1998). Private labels and the channel relationship: A crosscategory analysis. The Journal of Business, 71(4), 573-600.

Prendergast, G. P., \& Marr, N. E. (1997). Generic products: who buys them and how do they perform relative to each other? European Journal of Marketing, 31(2), 94-109.

Putsis, W. P. J., \& Cotterill, R. W. (1999). Share, price and category expenditure Geographic market effects and private labels. Managerial and Decision Economics, 20(4), 175-187.

Rafiq, M., \& Collins, R. (1996). Lookalikes and customer confusion in the grocery sector: an exploratory survey. International Review of Retail Distribution \& Consumer Research, 6(4), 329-350. 
Richardson, P. S., Jain, A. K., \& Dick, A. (1996). Household store brand proneness: A framework. Journal of Retailing, 72(2), 159-185.

Sayman, S., \& Raju, J. S. (2004). Investigating the Cross-Category Effects of Store Brands. Review of Industrial Organization, 24, 129-141.

Semeijn, J., Riel, A. C. R. V., \& Ambrosini, A. B. (2004). Consumer evaluations of store brands: effects of store image and product attributes. Journal of Retailing and Consumer Services, 11(4), 247-258.

Steenkamp, J.-B. E. M., \& Dekimpe, M. G. (1997). The increasing power of store brands: Building loyalty and market share. Long Range Planning, 30(6), 917-930.

Wedel, M., \& Zhang, J. (2004). Analyzing Brand Competition Across Subcategories. JMR, Journal of Marketing Research, 41(4), 448-456.

Wolinsky, A. (1987). Brand Names and Price Discrimination. The Journal of Industrial Economics, 35(3), 255-268.

Zielke, S., \& Dobbeistein, T. (2007). Customers' willingness to purchase new store brands. Journal of Product \& Brand Management, 16(2), 112-121. 
$\underline{\text { Table I: Items and source of constructs }}$

\begin{tabular}{|c|c|c|c|c|}
\hline Constructs & Measurement Items & $\begin{array}{l}\text { Factor } \\
\text { Loading }\end{array}$ & $\begin{array}{l}\text { Average } \\
\text { Variance } \\
\text { extracted }\end{array}$ & Sources \\
\hline $\begin{array}{l}\text { Consequences } \\
\text { of Purchase } \\
\text { Mistake }\end{array}$ & $\begin{array}{l}\text { Family and friends think less of } \\
\text { me } \\
\text { Be financially worse off }\end{array}$ & $\begin{array}{l}0.79 \\
0.57\end{array}$ & 0.25 & $\begin{array}{l}\text { Batra and Sinha, (2000) } \\
\text { Dunn et al., (1986) }\end{array}$ \\
\hline $\begin{array}{l}\text { Quality } \\
\text { variability }\end{array}$ & $\begin{array}{l}\text { Basically the same in quality } \\
\text { No significant quality difference } \\
\text { Does not vary a lot in terms of } \\
\text { quality }\end{array}$ & $\begin{array}{l}0.74 \\
0.80 \\
0.76\end{array}$ & 0.70 & Batra and Sinha, (2000) \\
\hline $\begin{array}{l}\text { Search vs } \\
\text { experience }\end{array}$ & $\begin{array}{l}\text { Information on packaging tells } \\
\text { everything } \\
\text { Description on packaging covers } \\
\text { features }\end{array}$ & $\begin{array}{l}0.61 \\
0.70\end{array}$ & 0.32 & $\begin{array}{l}\text { Batra and Sinha, (2000) } \\
\text { Erdem \& Swait, (1998) }\end{array}$ \\
\hline $\begin{array}{l}\text { Price } \\
\text { consciousness }\end{array}$ & $\begin{array}{l}\text { Compare prices before buying } \\
\text { Important to get the best price } \\
\text { Price is the most important } \\
\text { factor }\end{array}$ & $\begin{array}{l}0.77 \\
0.81 \\
0.72\end{array}$ & 0.67 & $\begin{array}{l}\text { Ailawadi et al., (2001) } \\
\text { Batra and Sinha, (2000) }\end{array}$ \\
\hline $\begin{array}{l}\text { Price-Quality } \\
\text { perception }\end{array}$ & $\begin{array}{l}\text { The higher the price the better } \\
\text { the quality } \\
\text { Your get what you pay for } \\
\text { Price is a good indicator of } \\
\text { quality }\end{array}$ & $\begin{array}{l}0.80 \\
0.67 \\
0.87\end{array}$ & 0.71 & $\begin{array}{l}\text { Lichenstein et al., } \\
\text { (1993) }\end{array}$ \\
\hline Brand Loyalty & $\begin{array}{l}\text { Continue to buy not considering } \\
\text { others } \\
\text { Make effort to search for } \\
\text { favourite brand } \\
\text { Care a lot about the brand } \\
\text { bought }\end{array}$ & $\begin{array}{l}0.76 \\
0.58 \\
0.57\end{array}$ & 0.55 & $\begin{array}{l}\text { Ailawadi et al., (2001) } \\
\text { Garretson et al., (2002) }\end{array}$ \\
\hline PLB Purchase & $\begin{array}{l}\text { Buy national brands (1) or } \\
\text { private labels }(5)\end{array}$ & & & Batra and Sinha, (2000) \\
\hline
\end{tabular}


Table II: Construct mean scores by category

\begin{tabular}{|l|c|c|c|c|c|c|c|c|}
\hline $\begin{array}{l}\text { Product } \\
\text { category }\end{array}$ & $\begin{array}{l}\text { PLB } \\
\text { Share } \\
\%\end{array}$ & $\begin{array}{l}\text { Private } \\
\text { label } \\
\text { purchase }\end{array}$ & $\begin{array}{l}\text { Price } \\
\text { conscious }\end{array}$ & $\begin{array}{l}\text { Brand } \\
\text { Loyalty }\end{array}$ & $\begin{array}{l}\text { Quality } \\
\text { variability }\end{array}$ & $\begin{array}{l}\text { Price } \\
\text { Quality }\end{array}$ & $\begin{array}{l}\text { Purchase } \\
\text { Mistake }\end{array}$ & $\begin{array}{l}\text { Search } \\
\text { v Exp. }\end{array}$ \\
\hline Canned fruit & 33 & $* 2.82$ & $4.61^{*}$ & 4.25 & 4.35 & 3.94 & 2.6 & 3.93 \\
\hline Toilet tissue & 28 & 2.63 & 4.36 & 4.43 & 4.57 & 4.63 & 2.5 & 4.07 \\
\hline Fresh Milk & 50 & 2.38 & 3.85 & 4.25 & $3.60 *$ & $3.70 *$ & 2.65 & 4.4 \\
\hline Cheese & 28 & 2.32 & 4.20 & 5.00 & 5.10 & 4.43 & 2.65 & 3.58 \\
\hline Fruit Juice & 9 & 2.33 & 4.12 & 5.00 & $5.34 *$ & 4.51 & 2.78 & 3.86 \\
\hline Potato Chips & 13 & 2.37 & 3.95 & 4.50 & 4.62 & 3.88 & 2.18 & 3.73 \\
\hline Biscuits & 9 & 2.23 & 4.18 & 4.89 & 4.89 & 4.13 & 2.48 & 3.65 \\
\hline Bread & 0 & 2.22 & 3.52 & 5.00 & 5.05 & 4.18 & 2.26 & $3.52^{*}$ \\
\hline $\begin{array}{l}\text { Breakfast } \\
\text { Cereal }\end{array}$ & 16 & 2.05 & 3.93 & 5.08 & 4.88 & 4.36 & 3.00 & 3.84 \\
\hline Pet food & 6 & 2.00 & 3.71 & 5.10 & 5.00 & 4.62 & 2.3 & 3.88 \\
\hline Total & $\mathbf{6 0 0}$ & $\mathbf{2 . 3 4}$ & $\mathbf{4 . 0 4}$ & $\mathbf{4 . 7 8}$ & $\mathbf{4 . 7 5}$ & $\mathbf{4 . 2 3}$ & $\mathbf{2 . 5 4}$ & $\mathbf{3 . 5 5}$ \\
\hline F value & & 3.4 & 3.0 & 3.6 & 8.9 & 4.2 & 3.0 & 3.2 \\
\hline Significance & & 0.00 & 0.002 & 0.00 & 0.00 & 0.000 & 0.002 & 0.001 \\
\hline $\begin{array}{l}\text { B\&S } \\
\text { comparison }\end{array}$ & $\mathbf{7 5 3}$ & $\mathbf{2 . 4 0}$ & $\mathbf{3 . 2 9}$ & $\mathbf{N} / \mathbf{A}$ & $\mathbf{4 . 4 7}$ & $\mathbf{N} / \mathbf{A}$ & $\mathbf{4 . 2 2}$ & $\mathbf{3 . 3 3}$ \\
\hline
\end{tabular}

$*$ = Significant difference with other categories - Sheffe test $\mathrm{p}<0.05$. 
Table III. A Regression model of attitude to private label purchase

\begin{tabular}{|l|c|c|c|}
\hline Independent Variable & Standardised coefficient & T-value & Sig. \\
\hline Price consciousness & 0.264 & 6.575 & 0.000 \\
\hline Price-quality association & -0.099 & -2.558 & 0.011 \\
\hline Brand loyalty & -0.199 & -4.486 & 0.000 \\
\hline Quality variability & -0.095 & -2.068 & 0.039 \\
\hline Purchase Mistake & 0.065 & 1.671 & 0.095 \\
\hline Search v. Exp & -0.011 & 0.277 & 0.782 \\
\hline Sample Size & 600 & F-value & \\
\hline$R^{2}$ & 0.20 & 24.5 & 0.000 \\
\hline
\end{tabular}


$\underline{\text { Table IV: Regression analysis by product category }}$

\begin{tabular}{|l|c|c|c|c|c|c|c|c|}
\hline Category & $\mathrm{R}^{2}$ & $\begin{array}{c}\text { Sig. } \\
\mathrm{p} \\
\text { value }\end{array}$ & $\begin{array}{c}\text { Price } \\
\text { conscious }\end{array}$ & $\begin{array}{c}\text { Price- } \\
\text { quality } \\
\text { association }\end{array}$ & $\begin{array}{c}\text { Brand } \\
\text { loyalty }\end{array}$ & $\begin{array}{c}\text { Quality } \\
\text { Variability }\end{array}$ & $\begin{array}{c}\text { Purchase } \\
\text { Risk }\end{array}$ & $\begin{array}{c}\text { Search v. } \\
\text { Exp }\end{array}$ \\
\hline Canned fruit & 0.331 & 0.001 & $0.532^{*}$ & -0.047 & -0.160 & -0.091 & 0.163 & -0.127 \\
\hline Biscuits & 0.308 & 0.003 & 0.119 & $-0.225 \#$ & $-0.321 \#$ & -0.067 & -0.029 & 0.049 \\
\hline Toilet tissue & 0.293 & 0.004 & 0.043 & -0.060 & $-0.286^{*}$ & $-0.428^{*}$ & 0.023 & -0.059 \\
\hline Pet food & 0.329 & 0.001 & $0.238 \#$ & -0.145 & $-0.253 \#$ & -0.214 & 0.071 & -0.34 \\
\hline Fresh milk & 0.249 & 0.015 & $0.425 \#$ & -0.007 & $-0.290 \#$ & -0.250 & 0.074 & 0.091 \\
\hline Bread & 0.280 & 0.002 & $0.238 \#$ & 0.021 & $-0.364^{*}$ & 0.003 & -0.143 & 0.032 \\
\hline Breakfast cereal & 0.264 & 0.010 & $0.310^{*}$ & -0.086 & $-0.256 \#$ & -0.035 & 0.212 & -0.096 \\
\hline Fruit juice & 0.293 & 0.004 & $0.285^{*}$ & -0.215 & $-0.311 \#$ & 0.042 & 0.209 & 0.117 \\
\hline Cheese & 0.178 & 0.097 & $0.346^{*}$ & -0.151 & 0.108 & -0.188 & -0.001 & -0.247 \\
\hline Potato Chips & 0.025 & 0.936 & -0.062 & -0.077 & -0.078 & 0.036 & -0.104 & 0.070 \\
\hline
\end{tabular}

Sample size is 60 per category

* Standardised regression co-efficient significant $p<0.05$.

\# Standardised regression co-efficient significant $p<0.10$. 
$\underline{\text { Table V. Regression model of attitude to private label purchase by market share }}$

\begin{tabular}{|l|c|c|c|c|c|c|}
\hline \multicolumn{3}{|c|}{ High PLB share } & \multicolumn{4}{c|}{ Low PLB share } \\
\hline $\begin{array}{l}\text { Independent } \\
\text { Variable }\end{array}$ & $\begin{array}{l}\text { Standardised } \\
\text { coefficient }\end{array}$ & T-value & Sig. & $\begin{array}{l}\text { Standardised } \\
\text { coefficient }\end{array}$ & T-value & Sig. \\
\hline $\begin{array}{l}\text { Price } \\
\text { consciousness }\end{array}$ & 0.342 & 5.353 & 0.000 & 0.199 & 3.824 & 0.000 \\
\hline $\begin{array}{l}\text { Price-quality } \\
\text { association }\end{array}$ & -0.059 & -0.944 & 0.346 & -0.127 & -2.531 & 0.012 \\
\hline Brand loyalty & -0.100 & -1.461 & 0.145 & -0.262 & 4.457 & 0.000 \\
\hline $\begin{array}{l}\text { Quality } \\
\text { variability }\end{array}$ & -0.087 & -1.147 & 0.253 & -0.079 & -1.360 & 0.175 \\
\hline $\begin{array}{l}\text { Purchase } \\
\text { Mistake }\end{array}$ & 0.074 & 1.188 & 0.236 & 0.600 & 1.173 & 0.241 \\
\hline Search v. Exp & -0.000 & 0.010 & 0.992 & -0.16 & -0.301 & 0.763 \\
\hline Sample Size & 240 & F-value & & 360 & F-value & \\
\hline$R^{2}$ & 0.19 & 9.1 & 0.000 & 0.197 & 14.5 & 0.000 \\
\hline
\end{tabular}

